\title{
UNDERSTANDING CHANGES IN DOCTOR MORAL HAZARD BEHAVIOUR IN RESPONSE TO GOVERNMENT HEALTHCARE REFORM
}

\begin{abstract}
Yaohui Wang ${ }^{1}$, Lina $\mathrm{He}^{2}$, Quanlong $\mathrm{Liu}^{1}$, Xinchun $\mathrm{Li}^{1}$
Abstract: Doctor moral hazard has a significant effect on the doctor-patient relationship, increases the cost of healthcare, and introduces medical risks. It is a global concern. Doctor moral hazard behaviour is evolving in response to China's healthcare reform program which was inaugurated in 2009. A scientific understanding of doctor behaviour would facilitate the prevention and control of doctor moral hazard behaviour. This study used the principles and methodology of Glaser and Strauss's grounded theory. Theoretical and snowball samplings were used to identify 60 subjects. Semi-structured in-depth interviews were conducted with each subject. Themes were identified through substantial (open) coding and theoretical coding. Six types of doctor moral hazard behaviour were extracted from the data. A behavioural model was described and diagrammed to provide a conceptual framework of current doctor moral hazard behaviour. The conceptual model of doctor moral hazard behaviour can be used in several ways to correct or prevent undesirable actions. Rules governing hospital procedures can be strengthened and enforced by supervision and punishment; the asymmetry of information between doctor and patient can be reduced; patient participation in treatment decisions can be increased; the effectiveness of medical ethics education can be improved.
\end{abstract}

Keywords: moral hazard, behaviour, grounded theory, doctor, semi-structured in-depth interviews

Entendiendo los cambios en el riesgo moral del comportamiento médico en respuesta a la reforma de atención de salud del gobierno

Resumen: Para un médico, el riesgo moral tiene un efecto significativo en la relación médico-paciente, incrementa el costo de la atención de salud e introduce riesgos en la salud. Se trata de una preocupación global. El riesgo moral del comportamiento médico ha evolucionado en respuesta al programa de reforma de atención de salud del gobierno de China, inaugurado en 2009. Un entendimiento científico del comportamiento de los médicos facilitaría la prevención y el control del riesgo moral. El presente estudio usa los principios y metodología de la teoría fundamentada de Glaser y Strauss. Se usaron muestras teóricas y multiplicativas para identificar 60 sujetos y realizar entrevistas semiestructuradas en profundidad. Los temas se identificaron mediante codificación sustancial abierta y teórica. De los datos se extrajeron seis tipos de riesgo moral del comportamiento médico. Se describió y diagramó un modelo de comportamiento para proporcionar una estructura conceptual del riesgo moral del comportamiento médico actual. El modelo conceptual de riesgo moral del comportamiento médico puede usarse de varias maneras para corregir o prevenir acciones no deseadas. Las normas procedimentales de los hospitales pueden fortalecerse y exigirse mediante supervisión y castigo; se puede reducir la asimetría de la información que se da entre el médico y el paciente, incrementar la participación del paciente en decisiones de tratamiento y mejorar la efectividad en la educación en ética médica.

Palabras clave: riesgo moral, comportamiento, teoría fundamentada, médico, entrevistas semiestructuradas en profundidad

Compreendendo mudanças no comportamento de risco moral médico em resposta a reforma governamental de cuidados à saúde

Resumo: Risco moral médico tem um efeito significativo na relação médico-paciente, aumenta o custo dos cuidados à saúde e introduz riscos médicos. É uma preocupação global. Comportamento de risco moral médico vem se desenvolvendo em resposta ao programa de reforma de cuidados à saúde da China, que se iniciou em 2009. Uma compreensáo científica do comportamento médico facilitaria a prevençáo e controle do comportamento de risco moral médico. Este estudo utilizou os princípios da metodologia da Teoria Fundamentada de Glaser e Strauss. Amostragem teóricas e por bola de neve foram utilizadas para identificar 60 participantes. Entrevistas detalhadas semi-estruturadas foram realizadas com cada participante. Temas foram identificados através de codificação (aberta) substancial e codificação teórica. Seis tipos de comportamento de risco moral médico foram obtidos dos dados. Um modelo comportamental foi descrito e diagramado de forma a fornecer um enquadre conceitual do comportamento de risco moral médico. O modelo conceitual de comportamento de risco moral médico pode ser utilizado de diversas formas para corrigir ou prevenir açôes indesejáveis. Regras que governam procedimentos em hospitais podem ser fortalecidas e reforçadas por supervisão e punição; a assimetria de informaçôes entre médicos e pacientes pode ser reduzida; a participação dos pacientes nas decisôes sobre tratamento pode ser aumentada; e a efetividade da educação ética médica pode ser melhorada.

Palavras chave: risco moral, comportamento, Teoria Fundamentada, médico, entrevistas detalhadas semi-estruturadas

${ }^{1}$ Jiangsu Universities (Safety Management Research Center), School of Management, China University of Mining \& Technology, Xuzhou, China. Taizhou Hospital of Zhejiang Province, Taizhou, China

Correspondence: ezwyh@163.com

${ }^{2}$ Taizhou Hospital of Zhejiang Province, Taizhou, China 


\section{Introduction}

Moral hazard is inevitable in healthcare services because of information asymmetry. Generally speaking, moral hazard includes both the moral hazards of the demander and the supplier(1). The central agent in supplier moral hazard is the doctor. Doctor moral hazard has led to rapid growth in medical costs in various countries. For example, healthcare expenditure in the United States rose from 26.9 billion USD in 1960 to $1,149.1$ billion USD in 1988, accounting for $14 \%$ of GDP(2).On 23 March 2010, President Barack Obama signed into law the Patient Protection and Affordable Care Act to reduce the costs of healthcare for both individuals and the government(3). Doctor moral hazard is generally believed to be caused by information asymmetry, opportunity and self-rationalisation(4). Arrow suggested that the concept of moral hazard could be applied to healthcare in 1963. He observed that the differences in patient health could be accurately assessed by doctors, due to their professional training, and that doctors were also capable of creating demand for medical services(5). For example, a doctor could ask a patient to undergo expensive tests. In medical insurance, the moral hazard of healthcare providers is the opportunistic behaviour by which, driven by their own economic interests, they take advantage of the information they possess and thus increase the cost of medicine.

The theory of information economics shows that moral hazard is an opportunistic behaviour. Doctors' moral hazard refers to opportunistic behaviour that maximises the interests of doctors while might damage those of patients. Some researchers also contend that doctors' moral hazard refers to doctors' induced demand. For example, research has shown that moral hazard in healthcare is concentrated around medication, hospitalisation, and patient examinations(6). Evans found that doctor moral hazard was manifest in examinations, medication and fees, such as unnecessary or expensive examinations, and expensive or overused medications(7). Later research showed that overcharging and receiving monetary gifts, which are not treatment-related activities, were part of doctor moral hazard(8). Doctor moral hazard is primarily explained by information asymmetry, opportunity, and self-rationalization and it di- rectly leads to increased medical costs. At present, there is limited detailed research on individual doctor behaviour regarding doctor moral hazard. Some doctors' moral hazard behaviours have not been studied, such as doctors 'reduction in standards for surgical indications, excessive use of surgical consumables in violation of treatment principles, and other malpractices. Thus, as an activity that is evolving, doctors' moral hazard behaviour needs to be studied.

In April 2009, China initiated a medical reform policy and introduced a series of measures that were intended to rebuild the healthcare system and emphasise the government's leadership of public welfare. The control of medical expenditure and the supervision of medical activity have gradually become the focus of medical reform. The U.S. government similarly proposed a health care reform plan in 2010 to resolve the problems of rapidly increasing medical costs and greater health safety risks(3). These problems are also related to medical practice and doctor moral hazard.

Doctor behaviour has changed subtly as more attention has been paid to doctor moral hazard. Health authorities and social security departments have increasingly supervised medical practices. Hospital assessment has gradually incorporated the examination of items such as average drug costs, duration of hospitalisation and inspection costs. Medical reform has reached a crucial stage. The key to the eventual success of medical reform initiatives is the behaviour of medical practitioners. If doctor moral hazard cannot be identified and controlled, it will be impossible to achieve substantial reform. It is therefore of great importance to conduct scientific research into doctor moral hazard in order to identify its mechanisms and develop appropriate prevention measures.

Doctors benefit from a high degree of information asymmetry, which enables them to adjust their specific moral hazard behaviour in different policy environments. There are no universal hypotheses of doctor moral hazard, and there has been limited research into it. Grounded theory is a qualitative research method created (or discovered) by Glaser and Strauss(9). It possesses the simplicity of traditional quantitative research and over comes the limitations of traditional qualita- 
tive research. The purpose of this study is to conduct a qualitative study of doctor moral hazard behaviour using grounded theory methods and techniques in order to gain a thorough and comprehensive understanding of the characteristics and changes in doctor moral hazard as medical reform progresses. This will enable us to identify ways to correct and control behaviour that serves doctor moral hazard(10).

This paper describes the internal structures of doctor moral hazard and identifies it by using grounded theory and qualitative research methods to create non-structural questionnaires to guide indepth interviews for classical samples.

\section{Methods}

Pandit divides the process following grounded theory into nine steps and groups them into five phases: review and discussion of relevant literature; case selection; development of strict data collection protocol; data collection; data ordering; data analysis of the first case; theoretical sampling; reaching closure; and comparison of the newly constructed theory with existing theories(11).

We used theoretical sampling as the basis of data collection. Theoretical sampling depends on the research goal and is part of grounded theory. A few initial sample cases are selected and explored in depth. The samples are considered to be richly representative data sources; this distinguishes the method from the large-scale random sampling commonly used in quantitative studies(12). The grounded theory requires that the theoretical samples must have breadth and depth of data, and research objectives may be changed dynamically according to the sample data until data decoding reaches some degree of saturation(13).

There are different conceptions of doctor moral hazard among patients, nurses, doctors and managers. There are young doctors and veteran experts who may have retired. There are small and large hospitals which differ in the services offered. We selected a range of interviewees from across these categories. The size of the sample was determined by theoretical saturation (i.e., sampling until a new sample no longer provides new information). We conducted in-depth interviews with
60 interviewees from September 2018 to December 2018. Interviewee characteristics are given in Table 1.

Table 1 Characteristics of interviewees.

\begin{tabular}{|c|c|c|c|}
\hline & Category & Number & Percentage $(\%)$ \\
\hline \multirow[t]{2}{*}{ Sex } & Male & 36 & 60 \\
\hline & Female & 24 & 40 \\
\hline \multirow[t]{4}{*}{ Age } & $<25$ years old & 10 & 16.7 \\
\hline & $26-35$ years old & 24 & 40 \\
\hline & $36-45$ years old & 12 & 20 \\
\hline & $>46$ years old & 14 & 23.3 \\
\hline \multirow[t]{4}{*}{ Job seniority } & $<3$ years & 0 & 0 \\
\hline & $3-10$ years & 18 & 30 \\
\hline & $10-20$ years & 30 & 50 \\
\hline & $>20$ years & 12 & 20 \\
\hline \multirow{4}{*}{$\begin{array}{l}\text { Educational } \\
\text { background }\end{array}$} & Medical doctor & 10 & 16.7 \\
\hline & Postgraduate & 12 & 20 \\
\hline & Undergraduate & 24 & 40 \\
\hline & Other & 14 & 13.3 \\
\hline \multirow{3}{*}{$\begin{array}{l}\text { Hospital } \\
\text { grade }\end{array}$} & Tertiary & 24 & 40 \\
\hline & Secondary & 18 & 30 \\
\hline & First & 18 & 30 \\
\hline \multirow[t]{4}{*}{ Job/role } & Doctor & 24 & 40 \\
\hline & Management & 10 & 16.7 \\
\hline & Nurse & 6 & 10 \\
\hline & Patient and family & 20 & 33.3 \\
\hline
\end{tabular}


Three days before the interview, we contacted the interviewees by telephone, email, WeChat (a mobile instant text and voice messaging communication service that has become an important social media platform in China) door-to-door visit, or other means to inform them of the purpose, format and topic of the interview. We also used this preliminary contact between the researchers and the interviewees to eliminate any communication obstacles(14),. The interviewees were prompted to summarise and reflect on their own work or patient experience and prepare for the interviews. The effectiveness of the formal interview can be ensured by the preliminary preparation for the interview, and a confirmation of the time and place can ensure the smooth progress of the formal interview.

During the formal interview, the researcher explained the concept of doctor moral hazard and the associated behaviours before conducting an in-depth interview. Doctor moral hazard is a sensitive issue among doctors. To ensure that doctors could discuss the issue honestly and not intentionally conceal relevant information, we used a question-changing technique in the interview. We collected the information we needed indirectly by presenting opinions from other hospitals and other medical practitioners (whom the interviewee knew) about the factors that influence doctor moral hazard(15). The main interview questions were as follows:

What do you know about doctor moral hazard and related behaviour in the context of the newlyintroduced healthcare reforms?

Do you know any patients who have encountered doctor moral hazard?

Apart from well-known doctor moral hazard activity, do you know any new types of doctor moral hazard activity?

What do you think are the types of doctor moral hazard behaviour?

What do you think are the inherent logical relationships among types of doctor moral hazard behaviour?

During the interview, we asked the interviewees to elaborate or explain their responses and some key points.

We adopted a face-to-face approach in the indepth interviews, intending to gain the trust of the interviewees through face-to-face communication and thereby encouraging the interviewees to express their thoughts without reservation. We also recorded the interviews to observe the facial expressions and body language of the interviewees and thereby gained insight into their psychology. The interview lasted for at least one hour to ensure the quality of the interview. After each interview, the researchers reflected on the interview to determine the direction of the next sample and recorded their observations and conclusions.

\section{Findings}

\section{Open coding}

Data gathered in the study were encoded using the qualitative data analysis tool NVivo11, which has considerable functionality to help researchers systematically collate and analyse unstruc-

Table 2 Concepts and categories derived by open coding.

\begin{tabular}{|l|l|l|l|}
\hline Number & Categories & Concepts & Frequency \\
\hline a1 & $\begin{array}{l}\text { Lack of timely } \\
\text { observation }\end{array}$ & $\begin{array}{l}\text { Doctors seldom come to ward rounds after surgery, and the wound } \\
\text { infection is unknown. The wound is too tight, and doctors do not } \\
\text { give decompression measures in time. }\end{array}$ & 52 \\
\hline a2 & $\begin{array}{l}\text { Expanding the } \\
\text { indication scope }\end{array}$ & $\begin{array}{l}\text { Such nodules do not require surgery abroad. Some of these surgeries } \\
\text { could have been replaced with less invasive treatment that produced } \\
\text { equally good results. }\end{array}$ & 33 \\
\hline a3 & $\begin{array}{l}\text { Using irrelevant } \\
\text { drugs }\end{array}$ & $\begin{array}{l}\text { It does not matter whether the drug is used or not. This medication } \\
\text { does not have an effect. Side effects are ignored, or patients are not } \\
\text { aware of them. }\end{array}$ & 24 \\
\hline
\end{tabular}




\begin{tabular}{|c|c|c|c|}
\hline a4 & Overuse & $\begin{array}{l}\text { This cannot be strictly used according to regulations. The number } \\
\text { of times the drug is used is strictly limited, but the actual number of } \\
\text { times doctors have used it has exceeded the limits. }\end{array}$ & 60 \\
\hline a5 & $\begin{array}{l}\text { Violating the } \\
\text { core medical } \\
\text { system }\end{array}$ & $\begin{array}{l}\text { A consultation isnot suggested in time, and a conference is missed. } \\
\text { Failure to report to the senior doctor in time worsened the illness. } \\
\text { Case discussion among all personnel in the hospital that should have } \\
\text { been organised doesnot occur. }\end{array}$ & 31 \\
\hline a6 & $\begin{array}{l}\text { Introducing new } \\
\text { technology }\end{array}$ & $\begin{array}{l}\text { Recommending minimally invasive techniques that have not been } \\
\text { widely taught domestically. Intentionally saying that the disease } \\
\text { requires an unconventional surgical path. }\end{array}$ & 45 \\
\hline a7 & $\begin{array}{l}\text { Preferential use } \\
\text { of imported } \\
\text { consumables. }\end{array}$ & $\begin{array}{l}\text { Doctors say imported consumables are of good quality and } \\
\text { domestically produced ones are prone to problems or have an } \\
\text { inadequate service life. }\end{array}$ & 28 \\
\hline a8 & $\begin{array}{l}\text { Receiving gift } \\
\text { money }\end{array}$ & $\begin{array}{l}\text { Patients will greatly benefit from giving doctors monetary gifts before } \\
\text { surgery, including the appropriate operation time and sequence. } \\
\text { Doctors who do not receive monetary gifts will not perform surgery. }\end{array}$ & 28 \\
\hline a9 & $\begin{array}{l}\text { Inclination to } \\
\text { perform surgery } \\
\text { surgery }\end{array}$ & $\begin{array}{l}\text { Doctors do not recommend conservative treatment. The hospital } \\
\text { suggests surgery, emphasising that surgery is better than the } \\
\text { conservative treatment. Doctors show great enthusiasm for surgery } \\
\text { when discussing treatment options. }\end{array}$ & 32 \\
\hline a10 & $\begin{array}{l}\text { Inclination } \\
\text { to prescribe } \\
\text { imported and } \\
\text { expensive drugs }\end{array}$ & $\begin{array}{l}\text { The reasons for using expensive drugs are rarely explained in detail. } \\
\text { Expensive drugs are often used before being identified. You will never } \\
\text { know the reason unless you ask about it. Although we ask for advice, } \\
\text { we actually had no choice. }\end{array}$ & 34 \\
\hline a11 & Drug overuse & $\begin{array}{l}\text { Preference to prescribe more medication. When discharged from the } \\
\text { hospital, patients are still required to take more medication and take } \\
\text { it for a long time. }\end{array}$ & 44 \\
\hline a12 & $\begin{array}{l}\text { Consumables } \\
\text { overuse }\end{array}$ & $\begin{array}{l}\text { Consumables are not neededaccording to treatment needs. More } \\
\text { consumables are used on the grounds of satisfying basic medical care. }\end{array}$ & 23 \\
\hline a13 & $\begin{array}{l}\text { Examination } \\
\text { upgrading }\end{array}$ & $\begin{array}{l}\text { In addition to basic examinations, higher-level examinations are } \\
\text { required to review a case. Even if the diagnosis is confirmed, a more } \\
\text { thorough examination will be required for an exclusive diagnosis. }\end{array}$ & 52 \\
\hline a14 & $\begin{array}{l}\text { Frequent } \\
\text { examination }\end{array}$ & Unnecessary examinations are repeated. & 23 \\
\hline a15 & $\begin{array}{l}\text { Extension of } \\
\text { hospital stay }\end{array}$ & $\begin{array}{l}\text { The patient who could have been discharged from the hospital earlier } \\
\text { still occupies a bed. Doctors do not want beds to be vacant. They will } \\
\text { not consider discharging patients from the hospital until new in- } \\
\text { patients are admitted. }\end{array}$ & 48 \\
\hline a16 & $\begin{array}{l}\text { Lowering the } \\
\text { hospitalisation } \\
\text { standard }\end{array}$ & $\begin{array}{l}\text { For a disease like this, it does not matter whether the patient } \\
\text { needshospitalisation. There are vacant beds, and doctors must fill } \\
\text { them up. }\end{array}$ & 32 \\
\hline a17 & $\begin{array}{l}\text { Inadequate } \\
\text { sterilising }\end{array}$ & $\begin{array}{l}\text { Doctors do not disinfect themselves or equipment according to } \\
\text { protocol. Disinfection is not complete, or the disinfection quality is } \\
\text { bad. }\end{array}$ & 29 \\
\hline a18 & $\begin{array}{l}\text { Irrelevant } \\
\text { examinations }\end{array}$ & $\begin{array}{l}\text { Some examination procedures are unnecessary; they are explained } \\
\text { by doctors as a group of examinations as if they are required by } \\
\text { government regulations. As soon as a patient is admitted to the } \\
\text { hospital, a lot of inexplicable examinations are given. }\end{array}$ & 32 \\
\hline
\end{tabular}


tured data. Encoding is part of grounded theory methodology. Using the software, 60 cases of respondents and 285 reference points were coded. After deletion and merging, 151 initial concepts were obtained, and 18 categories (a1-a18) were obtained after induction and sorting (Table 2). Six main categories (A1-A6) were further obtained by selective coding based on the structure, context and type relationships (Table 3 ). We discussed theories and practice during the coding process with experts to avoid subjective bias and predetermined conclusions.

\section{Selective coding}

We reviewed and scrutinised each category, and on the basis of medical practice, we extracted six main categories (excessive examinations, excessive medications, excessive consumables, excessive hospitalisation, excessive surgery and dereliction of duty). It should note that as the most important concern for hospitalised patients is excessive surgery, it is considered to be the core and selective coding higher category shown in the table. We analysed the behaviour characteristic of all six main categories (Table 3).

\section{Selective coding and model building}

Further analysis, based on the results of selective coding, showed that dereliction of duty covers all the behavioural characteristics associated with doctor moral hazard. Doctor behaviour acts against patient interests when doctors maximise their own interests. Such behaviour includes not changing equipment, not disinfecting or sterilising themselves or their equipment according to protocols, and receiving monetary gifts despite prohibitive regulations, violating the core medical doctor-patient relationship. These kinds of doctor behaviour are of general importance. The other five kinds of doctor behaviour are associated with excessive treatment, including over-examination of patients, unnecessarily prolonged hospitalisation, overuse of consumables and inappropriate medication or overmedication.

The key to altering these behaviours is to review the treatment process; that is, to monitor whether the process conforms to medical protocols and to review the necessity of each procedure. Beginning with the admission of a patient, the first problem to address is excessive examinations. Doctors need to make many kinds of examination in diag-

Table 3 Main categories of open coding.

\begin{tabular}{|c|c|c|c|c|}
\hline & Main category & Category & Frequency & Percentage \\
\hline A1 & $\begin{array}{l}\text { Dereliction of } \\
\text { duty }\end{array}$ & $\begin{array}{l}\text { a1 Lack of timely observation } \\
\text { a4 Overuse } \\
\text { a5 Violating the core medical system } \\
\text { a8 Receiving gift money } \\
\text { a17 Inadequate sterilising }\end{array}$ & 28 & 22.8 \\
\hline A2 & $\begin{array}{l}\text { Excessive } \\
\text { surgery }\end{array}$ & $\begin{array}{l}\text { a2 Expanding the indication scope } \\
\text { a6 Introducing new technology } \\
\text { a9 Inclination to perform surgery surgery }\end{array}$ & 22 & 17.9 \\
\hline A3 & $\begin{array}{l}\text { Excessive } \\
\text { examination }\end{array}$ & $\begin{array}{l}\text { a13 Examination upgrading } \\
\text { a14 Frequent examination } \\
\text { a18 Irrelevant examinations }\end{array}$ & 18 & 14.6 \\
\hline A4 & $\begin{array}{l}\text { Excessive } \\
\text { medication }\end{array}$ & $\begin{array}{l}\text { a3 Using irrelevant drugs } \\
\text { a10 inclination to prescribe imported and expensive } \\
\text { drugs } \\
\text { a11 Drug overuse }\end{array}$ & 25 & 20.3 \\
\hline A5 & $\begin{array}{l}\text { Excessive } \\
\text { consumables }\end{array}$ & $\begin{array}{l}\text { a7 Preferential use of imported consumables } \\
\text { a12 Consumables overuse }\end{array}$ & 18 & 14.6 \\
\hline A6 & $\begin{array}{l}\text { Excessive } \\
\text { hospitalisation }\end{array}$ & $\begin{array}{l}\text { a15 Extension of hospital stay } \\
\text { a16 Lowering the hospitalisation standard }\end{array}$ & 12 & 9.8 \\
\hline
\end{tabular}


nosis and treatment, but not all examinations are necessary. After an initial examination, doctors should evaluate whether a patient is an outpatient or an inpatient. During our interviews, medical personnel of large general hospitals talked about the relaxation of hospitalisation indicators in primary medical institutions. Patients who could have been treated as outpatients were admitted to hospital for treatment. After a patient was admitted, medical staff preferred surgery over conservative treatment. For example, the case of trauma patients was mentioned in an interview. Although the medical practitioners suggested surgical treatment, patients recovered well through less invasive treatment. This situation indicates potential doctor moral hazard. If a doctor's recommendation of surgery is followed, the patient would require surgical materials, narcotic drugs, and rehabilitation treatment after surgery. This shows that there are problems of excessive treatment: overmedication, unnecessary examinations, and surgery. Figure 2 shows how excessive procedures are linked to dereliction of duty.

\section{Discussion}

We used grounded theory (analysis, comparison and concentration of the original data, categorisation, and integration of the concepts that were identified) to extract six core aspects of doctor moral hazard. The unifying concept is dereliction of duty, which is manifest as unnecessary surgery, leading to excessive medication, unnecessary exa- minations, overuse of consumables, and needless hospitalisation. Doctor behaviour associated with moral hazard has greatly changed when compared to moral hazard behaviour described in the literature(16). Doctor moral hazard previously included excessive medication, unnecessary patient tests, and lengthy hospitalisation. However, as the medical reforms have been implemented in China and government supervision of medical practice has increased, unnecessary surgery, overuse of consumables, and probable malfeasance in doctor behaviour have also increased, because these behaviours are relatively more difficult to identify and control. This trend indicates that doctor moral hazard behaviour is changing in ways that make it less significant and more sophisticated. Three aspects of this trend confirm the accuracy of previous research, but we suggest there are new behaviours engendered by the implementation of the reform program.

Doctor behaviour is constantly adjusted. Doctors recognise changes in healthcare policy and covertly alter their behaviour. China's healthcare reforms had an effecting controlling the average length of stay, the administration of drugs, and total medical expenses. However, due to the pressures of increased supervision, tense doctorpatient relationships, and the high incidence of injuries requiring medical intervention, doctor behaviour has evolved. Increased government supervision has resulted in doctors becoming less straightforward and more circumspect when in-

Figure 1: Grounded theoretical research process.

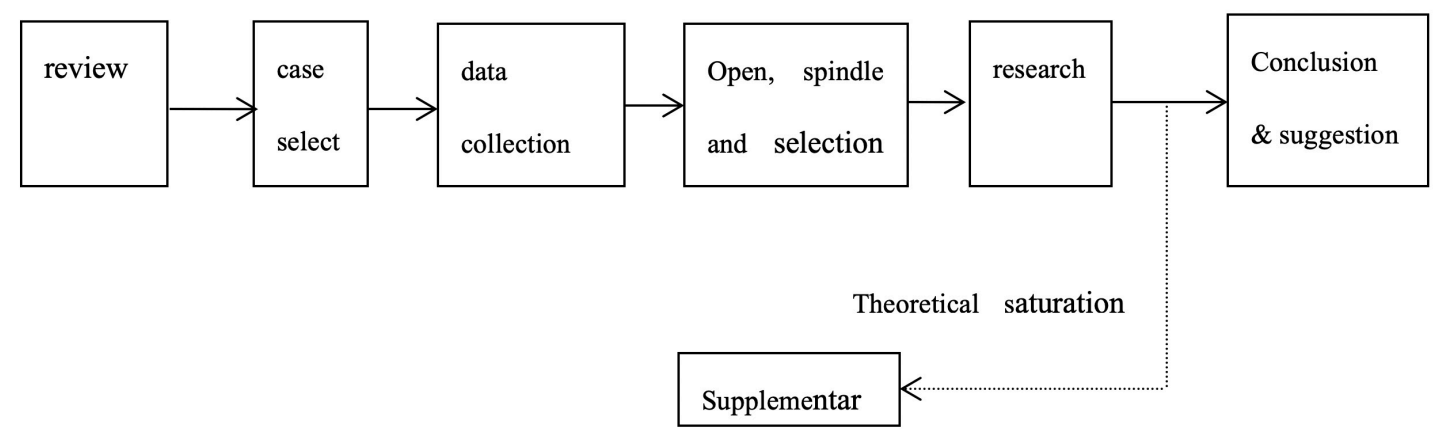




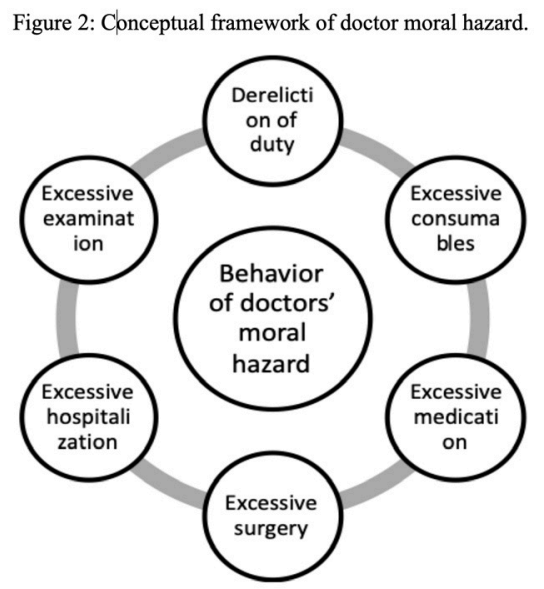

teracting with their patient interactions. Doctor behaviour has also changed from being safe and risk-free to less safe and riskier.

\section{Excessive examination}

Doctors make many kinds of examinations in the process of diagnosis and treatment, but not all examinations given are necessary. One doctor mentioned in the interview that if adequate examinations are not given, a patient would complain when a condition is not correctly diagnosed and even sue the hospital for compensation, on the grounds of delayed treatment(17). The same doctor observed that a patient hopes to get an adequate examination when seeing a doctor. Some examinations are by nature exclusory and thus have a Low positive outcome rate and may be considered to be excessive examinations by patients. Patient interviews showed that excessive examinations are common. If doctors are communicative and can obtain patient consent, patients would accept the examinations. Of course, some patients even ask for more tests to get their physical condition.

\section{Excessive medication}

Interviews with hospital employees and nursing staff indicated that doctors tend to prescribe and use expensive drugs, overprescribe and overuse drugs, and even prescribe and use prohibited drugs. Interviews with patients showed that the most unacceptable doctor behaviour is to prescri- be drugs that should not be administered or that have side effects. Sometimes, when a doctor prescribes expensive drugs over cheaper equivalent drugs or overprescribe drugs, the patients would think that they could benefit from the medication and so they are not greatly opposed to these practices (18).

\section{Excessive consumables}

The overuse of consumables is similar to the overuse of medication. Interviews with hospital employees and nursing staff showed that doctors prefer or overuse expensive consumables. Interviews with patients showed that the most unacceptable behaviour for patients was that doctors deliberately overused consumables, such as stents and other auxiliary consumables, which do not improve the patient's condition and even have potential side effects. However, patients were not opposed to the use of some expensive consumables that might benefit them.

\section{Dereliction of duty}

Dereliction of duty covers all the characteristics of doctor moral hazard behaviour. Doctor moral hazard results from doctors taking actions that are against patients' interests when, for example, the doctor maximises their own returns by not changing equipment and disinfecting or sterilising according to protocols, receiving money contrary to regulations, and perverting the delivery of core medical services. 


\section{Excessive surgery}

Given a choice between conservative treatment and surgery, doctors and other medical practitioners prefer surgery. Induced demand is a recognised phenomenon: surgeons naturally give priority to surgery for the sake of business. In the case of trauma patients, discussed in the interviews, doctors and medical staff suggest surgery. However, patients can recover from trauma through conservative treatment(19).

\section{Excessive hospitalisation}

After an examination, doctors would assess whether the patient can be treated as an outpatient or an inpatient. During our interviews, medical professionals in large general hospitals mentioned that the admittance requirements were relaxed in primary medical institutions. Patients who could have been treated as outpatients in the clinic were admitted to the hospital for treatment, suggesting the effects of doctor moral hazard. This kind of doctor moral hazard is often accompanied by excessive surgery.

Scientific knowledge of doctor moral hazard behaviour enables us to better study the manifestation of doctor moral hazard at micro-level (i.e., the factors that induce an individual doctor's behaviour) and how to formulate management countermeasures to prevent and control doctor moral hazard, thereby providing guidance to alleviate the imbalance in the doctor-patient relationship. Scientific understanding of doctor moral hazard can also provide a basis for the next macro-level reform of medicine and healthcare.

\section{Conclusion}

We used grounded theory to systematically study doctor moral hazard behaviour in the context of government medical reforms. The theory enabled us to develop a new interpretation of doctor moral hazard behaviour. Doctor behaviour has changed considerably from that described in the literature (20). Since the introduction of medical reform in China, behaviours described in previous literature are still practised, but new forms of behaviour have emerged. Current doctor moral hazard behaviour falls into six categories: dereliction of duty, excessive surgery, excessive examination and testing, excessive medication, excessive use of consumables, and excessive hospitalisation.

Accurate knowledge of doctor moral hazard behaviour and the trends of its change can be applied in many fields. In terms of laws, regulations and protocols, we must increase policing of the rules and punish unwanted behaviour to prevent the evolution of behaviours that emerge in response to the lack of regulatory enforcement. In terms of hospital management, we must reduce information asymmetry and increase patient's participation by redesigning system and process. We must also improve education in medical ethics so that medical practitioners can recognise doctor moral hazard behaviour and understand its consequences, thereby avoiding it. This is particularly important when the moral hazard affects the health of patient. Finally, we must make it harder for doctors to rationalise their moral hazard behaviour.

\section{Acknowledgement}

This work was supported bythe Think Tank of Energy Mining Economy (2018 "Double First-Class" Initiative Project for Cultural Evolution and Creation of CUMT) (Grant no. 2018WHCC01) and the Fundamental Research Funds for the Central Universities (Grant no. 2019CXNL07). 
Understanding changes in doctor moral hazard behaviour in response to government healthcare reform - Yaohui Wang et al.

\section{References}

1. Einav L, Finkelstein A. Moral Hazard in Health Insurance: What We Know and How We Know It. Journal of the European Economic Association 2018; 16(4): 957-982.

2. Levit K. Health Spending in 1998: Signals of Change. Health Affairs 2000; (1): 124-132.

3. Mendoza RL. Which moral hazard? Health care reform under the Affordable Care Act of 2010. Journal of Health Organization and Management 2016; 30(4): 510-529.

4. Lundin D. Moral hazard in physician prescription behavior. Journal of Health Economics 2000; 19(5): 639-662.

5. Arrow K. Uncertainty and the Welfare Economics of Medical Care. American Economic Review 1963; 53(5): 941-973.

6. Cromwel J, Mitchell JB. Physician-induced demand for surgery. Journal of Health Economics 1986; 5(4): 293-313.

7. Evans RG. Supplier Induced Demand: Some Empirical Evidence and Implications. The Economics of Health and Medical Care 1974; 162-173.

8. Doran E, Robertson J, Henry D. Moral hazard and prescription medicine use in Australia - the patient perspective. Social Science \& Medicine 2005; (60): 1437-1443.

9. Rose C, Howard R. Living with coeliac disease: a grounded theory study. Journal of Human Nutrition and Dietetics 2014; 27(1): 30-40.

10. Handberg C, Thorne S. Revisiting symbolic interactionism as a theoretical framework beyond the grounded theory tradition. Qualitative Health Research 2015; 25(8): 1023-1032.

11. Pandit NR. The Creation of Theory: A Recent Application of The Grounded Theory Method. The Qualitative Report 1996; 2(4): 1-13.

12. Harper D. Qualitative Analysis for Social Scientists by Anselm L. Strauss. Contemporary Sociology 1987; 3(5): 16-19.

13. Sy T. What do You Think of Followers? Examining the Content, Structure and Consequence of Implicit Followership Theories Organizational. Behavior and Human Decision Processes 2000; 113(2): 73-84.

14. Kathy C. Constructing Grounded Theory. Thousand Oaks: Sage Publication; 2006: 70-71.

15. Vedana KGG, Magrini DF, Miasso AI, Zanetti ACG, De Souza J, Borges TL. Emergency Nursing Experiences in Assisting People with Suicidal Behavior: A Grounded Theory Study. Archives Nursing 2017; 31(4): 345-351.

16. Fuchs VR. The supply of surgeons and the demand for operations. Journal of human resources 1978; 236(13 Suppl): 35-36.

17. Debpuur C, Dalaba MA, Chatio S, Adjuik M, Akweongo P. An exploration of moral hazard behaviors under the national health insurance scheme in Northern Ghana: a qualitative study. BMC Health 2015; 15: 469.

18. Sadeghi, Abuzar, Keshavarz, Ahmadzadeh, Alsadat M, Yusefi. Studying the amount of induced demand done MRI services in Shahid Chamran hospital of Shiraz on 2014. The Magazine Research of Health in Society 2015; 1(3): 33-40.

19. Cromwel J, Mitchell JB. Physician-induced demand for surgery. Journal of Health Economics 1986; 5(4): $293-313$.

20. Nash S, Rojas M, Hebert P, Marrone SR, Colgan C, Fisher LA, Caliendo G, Chassin MR. Reducing Excessive Medication Administration in Hospitalized Adults With Renal Dysfunction. American Journal of Medical Quality 2005; 20(2): 64-69.

Received: October 28, 2019

Accepted: November 22, 2019 